\title{
The Influence of Intellectual Capital On the Firm's Value with Profitability as Intervening Variable \\ (Empirical Study on Banking Subsector Companies Listed on the Indonesia Stock Exchange (IDX) of the year 2017-2019)
}

\author{
Rarassatika Ainunnisa*, Astrid Tania Damayanti and Nuryaman \\ Widyatama University, Bandung, Indonesia \\ *ainunnisa.rarassatika@widyatama.ac.id, tania.damayanti@widyatama.ac.id, nuryaman@widyatama.ac.id
}

Article History: Received:11 January 2021; Accepted: 27 February 2021; Published online: 5 April 2021

\begin{abstract}
The purpose of this study was to determine the effect of intellectual capital on firm's value with profitability as an intervening variable. Intellectual capital is calculated using Pulic's calculation model. The number of samples in this study were 81 financial statements of 27 banking subsector companies listed on the Indonesia Stock Exchange (IDX) of the year 2017-2019. The conclusions obtained from this study include: intellectual capital has a positive effect on profitability; intellectual capital has a positive effect on company value; profitability has a positive effect on firm's value; and intellectual capital has a positive effect on firm's value with profitability as an intervening variable.
\end{abstract}

Keywords: Intellectual capital, firm's value, profitability, intervening variable, IDX

\section{Introduction}

In the present era the economy world has developed rapidly, as evidenced by advances in information technology, increasingly fierce competition and continuous growth of innovation.

An effort to maximize company resources seem to have entered a paradigm shift that company management can no longer only rely on physical resources, but they need to maximize intellectual resources (Suhendah, 2012). The same physical resources can be owned by competing companies, while intellectual capital are not necessarily owned and difficult to imitate so that it can create a difference as an added value for capital to achieve competitive advantage.

According to Susanti (2021), company's value can be seen from the shares price. The shares price depends on the demand and supply of investors, so the shares price can be used as a representative of the company's value. If the shares price higher, the value of the company will also high. Price book value (PBV) is used to represent the value of a company. This is because PBV is better able to show the return on investment. The PBV ratio manifest how the market appreciates the book value of a company's shares, higher PBV represents that the market has more certainty in prospects of the company (Weston \& Copeland, 2008).

In increasing firm's value and company financial performance, intellectual capital is considered to play a crucial role (Mendra, 2012). If a company used intellectual efficiently, the company's financial performance would likely increase. With the increase in the company's financial performance, the company will get an exceptional feedback from the market, so the firm's value will also rise.

The more intellectual capital is considered as a source that creates and maintains competitive advantage and adds value to stakeholders, the more necessary to identify and measure intellectual capital itself. Value Added Intellectual Coefficient (VAIC ${ }^{\mathrm{TM}}$ ) used to measured intellectual capital in this study. VAIC ${ }^{\mathrm{TM}}$ exhibits how much new value can be created by each currency unit invested in company's resources. The more higher the coefficient, the more better the intellectual capital of a company in conceiving value for its stakeholders (Pulic, 2008).

The efficient use of all company assets, both tangible assets and intangible assets (in this case refer to intellectual capital) will rise the profits of the company. Investors can use financial ratios as a tool to analyze ability of a company to generate profits based on the stocks it owns. This shows that financial ratios are useful for assessing a company's financial condition. The value of the company's stock is reflected in the company's 
performance. If the company's financial condition shows good prospects, investors will increase the demand of that company's stocks and automatically the prices will rise (Asikin, 2020). The higher level of profit obtained by the company, the higher its financial performance. Return of Assets (ROA) is used to measure financial performance in this study.

Previous research has proved that the intellectual capital can be able to act as a particular resource to build competing advantage for companies because it is able to provide value added to the company (Handayani, 2020). In line with Nuryaman (2015), intellectual capital impact positively on the company's value. In other study, intellectual capital has a significant effect to profitability (Nugraha,2018). The result of other study by Utami (2020) is there was an effect of intellectual capital firm's value through profitability as a mediating variable. Based on these finding there are a causal Relation between intellectual capital and the firm's value, same goes with the intellectual capital and profitability. Profitability could be also possible to act as an intervening variable between intellectual capital and the firm's value in a causal Relation.

\section{Conceptual Framework}

\subsection{Intellectual capital (IC)}

Intellectual capital was first put forward by Tom Stewart, in June 1991 (Ulum, 2009) which is one of the resources owned by the company. Stewart defines intellectual capital as an economic value creator for companies that are oriented towards long-term sustainable growth. Intellectual capital also described as the difference between company's value of the market and its replacement assets. Company's market value is equal to the book value plus the company's intellectual capital (Nuryaman, 2015). Intangible assets that can be measured economically will be reported in financial reporting posts such as patents, trademarks and so on. But many intangible assets cannot be measured economically so they are reported through disclosures in notes on financial statements or other records (Rachmawati, 2020).

Intellectual capital is a capital that all assets and processes which usually do not appear on the balance sheet. Such as patents, trademarks, brands, and all intangible asset that have been considered against modern accounting methods which include the contribution of human knowledge from human knowledge itself as a company resource (Bontis, 2000).

Generally, researchers state that intellectual capital consists of three components; human capital, structural capital, and employed capital (Bontis \& Chun, 2002). Human capital known as the main element of intellectual capital, because it is where various kinds of innovations, creativity and quality can be represented by employee's knowledge and competencies, and all of that is part of the human capital of the organization. Structural capital is the capability of a company to execute its regular company processes and structures. The process and structure support employees in their efforts to produce the best intellectual performance and overall business performance, such as: company operating systems, manufacturing processes, organizational culture, management concepts and all Intellectual property company owned. Relation capital describes the harmonious Relation between the company and its partners, including reliable and high-quality suppliers, and loyal customers who are satisfied with the company's services. These Relations stem from the company's Relation with the government and surrounding communities.

Value Added Intellectual Coefficient or VAIC ${ }^{\mathrm{TM}}$ can be a method that will represent the value of intellectual capital. VAIC ${ }^{\mathrm{TM}}$ method was developed by Pulic in 1998, designed to measure how much and how effective the value added as a result of the intellectual capital the company owned. Stages to calculate intellectual capital using VAIC $^{\mathrm{TM}}$ model according to Pulic (2008) are assumed that VAIC ${ }^{\mathrm{TM}}$ is the sum of Value Added Capital Employed (VACA), Value Added Human Capital (VAHU), and Structural Capital Value Added (STVA). 


\subsection{Firm's value}

Viewpoint of company's success rate can be seen by investor with the firm's value, which is usually related to the shares price (Sujoko \& Soebiantoro, 2007). Shares price is a price that is a reference for investors in the stock market. One of the company's goals is to maximize its value. A high company value is the desire of company owners or shareholders because a high value means that the prosperity of shareholders is also high. Firm's value is defined as the present value of expected free cash flow, discounted at a weighted average cost of capital (Brigham \& Houston, 2013) and the actual amount per share of common stock that would be received if all of the firm's assets were sold for their market value (Gitman \& Chad, 2012).

Price book value (PBV) is used to measure the market value ratio in this study. The PBV ratio measures the value of the financial market could provide the management and organization of companies to grow continuously (Brigham \& Houston, 2013). The PBV ratio is a comparison between the shares price and equity's book value. If the ratio is high, that likely indicates the market is more confident with the prospect of its company.

\subsection{Profitability}

Profitability is capability of a company to gain profits in terms of sales, total assets, and capital (Sartono, 2010). Profitability is company's capability to achieve profits at a certain level of sales, assets, and share capital. So the profitability of a company's capability to earn profit, which illustrates the good or bad performance of the company seen from profits earned in a given period (Winarso \& Hyun, 2016). Return on assets (ROA) measures a company's capability to use its assets to generate profits (Prastowo \& Julianty, 2002).

\subsection{Relation between intellectual capital and profitability}

Resources-based theory states that if intellectual capital can be managed properly, it can create a competitive advantage for the company that would affects company performance. The better a company can manage and utilizes its intellectual capital, it will create distinctive competencies for the company which expected that it could support the ability of a company to meet customer needs. Companies with competitive advantage over competitors will have the opportunity to increase net income. This net profit is obtained by the company from the total revenue minus the company's expenses. To get an increased net profit, company needs to raise the revenue and lessen company's expenses. The increase in net income is influenced by the efficient use of company assets which consist of current assets, fixed assets, and others. By paying attention to the company's net income and managing company assets efficiently, ROA value will increase.

Research conducted by Chen (2005) reveal that intellectual capital has positive effect on ROA. If company able to manage and develop the intellectual capital it owns properly, it will efficiently manage the company's assets so that the company's net income will increase and generate a competitive advantage for the company.

\section{H1: Intellectual Capital positively take effect on Profitability.}

\subsection{Relation between intellectual capital and firm's value}

A competent and highly committed employee in the company can demonstrate company productivity and profitability. Competence and commitment need to be supported by company facilities. Financial funds/company physical assets are needed in order to have a good employees and supporting facilities. This combination shows that the company needs to show intellectual capital. Good productivity and profitability means good financial performance and attracts investors to invest in the company. Increasing intellectual capital as an opportunity to increase company value performed through profit creation, positioning strategies, innovation, consumer loyalty, reducing costs, and improving productivity (Ulum et al., 2008) 
The Influence of Intellectual Capital On the Firm's Value with Profitability as Intervening Variable (Empirical Study on Banking Subsector Companies Listed on the Indonesia Stock Exchange (IDX) of the year 2017-2019)

\section{H2: Intellectual Capital positively take effect on Firm's Value.}

\subsection{Relation between profitability and firm's value}

Profitability indicates grade of net profit that a company can obtain during its operations. Shareholders always want a profit from the investment they put in the company. Investors review the financial ratio as an investment evaluation tool to outline the company, because the financial ratio reflects the high and low value of the company. If investors want to know how much investment returns the company generates, then the first thing to look at is the profitability ratio. If the company manages to achieve a large profit rate, it will motivate investors to invest in stocks, so that the shares price and the demand for shares will increase. A financial performance that is proxied in profitability with the variable measurement of earnings per share has a positive effect on firm's value (Wijayani, 2017).

\section{H3: Profitability positively take effect on Firm's Value.}

\subsection{Profitability as an intervening variable in relation between intellectual capital and firm's value}

Resource-based theory states that if company can manage and use resources its capabilities, a company can compete competitively. This also would run well if the use of the resources owned is supported by the good intellectual ability of the company. When resources are managed efficiently and effectively, it can encourage increased performance for the company which will be responded to positively by stakeholders, and one of which is the investors. Value of a company will reflect in company's shares price. The better the stakeholder response, the better the company value. Research conducted by Chen (2005) proves that intellectual capital has a positive effect on company's performance and value. This research contradicts with Yuniasih (2010) that the research failed to prove that intellectual capital affects firm's value. Researcher views that other factors might influence this Relation. There is also researches that proves that there is a significant positive influence between intellectual capital on financial performance conducted by Rohman and Cahyo (2013), Wijayani (2017) and Oktari (2016).

\section{H4: Profitability mediates the influence of Intellectual Capital on the Firm's Value.}

\section{Methods}

\subsection{Operationalization of the study variables}

The operationalization of variables is carried out by observing the dimensions, sides, behavioral characteristics of a concept, then translating into elements that can be observed and measured so that an index for measuring these concepts can be created or developed (Nuryaman \& Christina, 2015).

\subsubsection{Intellectual capital}

The stages of calculating intellectual capital using the VAIC ${ }^{\mathrm{TM}}$ model of Pulic (2008) are as follows: 
Table 1. Stages to calculate VAIC ${ }^{\mathrm{TM}}$

\begin{tabular}{|c|c|c|}
\hline \multirow{2}{*}{ Calculating the Value Added (VA) } & $\mathrm{VA}=\mathrm{OUT}-\mathrm{IN}$ & $\begin{array}{l}\text { OUT = Output: total sales and other } \\
\text { revenue; IN = Input: sales expenses } \\
\text { and other costs (not including } \\
\text { personnel expenses). }\end{array}$ \\
\hline & $\mathrm{VA}=\mathrm{OP}+\mathrm{EC}+\mathrm{D}+\mathrm{A}$ & $\begin{array}{l}\text { OP = Operating profit (operating } \\
\text { profit); EC = Employee costs } \\
\text { (personnel expenses); D }= \\
\text { Depreciation (depreciation); } \quad \mathrm{A}= \\
\text { amortization. }\end{array}$ \\
\hline $\begin{array}{l}\text { Calculating the Value Added Capital } \\
\text { Employed (VACA). } \\
\text { VACA is a measure of VA produced per } \\
\text { unit of physical capital. }\end{array}$ & $\mathrm{VACA}=\mathrm{VA} / \mathrm{CE}$ & $\begin{array}{l}\text { VACA = Value Added Capital } \\
\text { Employed or VA ratio of CE; VA = } \\
\text { Value Added; CE = Capital } \\
\text { employed; available funds (derived } \\
\text { from net income, and equity) }\end{array}$ \\
\hline $\begin{array}{l}\text { Calculating the Value Added Human } \\
\text { Capital (VAHU). } \\
\text { This ratio shows the value added per } \\
\text { Rupiah invested in HC. This ratio shows } \\
\text { the contribution of each Rupiah invested } \\
\text { in HC to the VA organization. }\end{array}$ & $\mathrm{VAHU}=\mathrm{VA} / \mathrm{HC}$ & $\begin{array}{l}\text { VAHU = Value Added Human } \\
\text { Capital: The ratio of VA to HC. VA } \\
\text { = Value Added; HU = Human } \\
\text { Capital: personnel expenses. }\end{array}$ \\
\hline $\begin{array}{l}\text { Calculating Structural Capital Value } \\
\text { Added (STVA). } \\
\text { The ratio represents } 1 \text { SC used by the } \\
\text { company to obtain VA. }\end{array}$ & STVA $=\mathrm{SC} / \mathrm{VA}$ & $\begin{array}{l}\text { STVA = Structural Capital Value } \\
\text { Added: The ratio of the SC to the } \\
\text { VA; SC=Structural Capital: VA } \\
\text { reduced HC(VA-HC); VA= Value } \\
\text { Added }\end{array}$ \\
\hline $\begin{array}{l}\text { Calculating Value added intellectual } \\
\text { coefficient (VAIC). } \\
\text { VAIC determines the intellectual capacity } \\
\text { of an organization, which can be } \\
\text { regarded as BPI (Business Performance } \\
\text { Index) }\end{array}$ & $\mathrm{VAIC}^{\mathrm{TM}}=\mathrm{VACA}+\mathrm{VAHU}+$ & $\begin{array}{l}\text { VAIC is the sum of the previous } \\
\text { three components: VACA, VAHU } \\
\text { and STVA }\end{array}$ \\
\hline
\end{tabular}

\subsubsection{Firm's value}

Price to Book Value (PBV) is used to measure the firm's value variable. Stages for calculating the PBV ratio are as follows (Brigham \& Houston, 2013):

1. Calculate the share price

Share Price $(\mathrm{PV})=$ Price per share in the study period

2. Calculating Book Value (BV) $=$ Book value of shareholders' equity divided by the number of shares outstanding

3. Calculating the Price to Book Value (PBV) Ratio

$\mathrm{PBV}$ ratio $=$ Share Price $/$ Book Value

\subsubsection{Profitability}

The calculation of profitability will use the ROA ratio, while the stages of calculating the ROA ratio are with the following formula (Brigham \& Houston, 2013):

ROA $=($ EAT $) /($ Total Assets $) \times 100 \%$ 
The Influence of Intellectual Capital On the Firm's Value with Profitability as Intervening Variable (Empirical Study on Banking Subsector Companies Listed on the Indonesia Stock Exchange (IDX) of the year 2017-2019)

\subsection{Population and sample}

This study population were all banking public subsector companies that listed on IDX of the year 20172019 period and the number of samples used was 27 companies, so the data collected were 81 company's financial statements which is the research sample.

\subsection{Analysis model}

This study analyzed the data which has been collected. Path analysis is used to proceed and analysis the data in this study.

\section{Results and Discussion}

4.1 Relation between intellectual capital and profitability in banking public subsector that listed in Indonesia Stock Exchange (IDX)

Table 2. Results intellectual capital - profitability

\section{Coefficients $^{\mathrm{a}}$}

\begin{tabular}{|c|c|c|c|c|c|c|}
\hline \multirow[b]{2}{*}{ Model } & & \multicolumn{2}{|c|}{ Unstandardized Coefficients } & \multirow{2}{*}{$\begin{array}{c}\text { Standardized } \\
\text { Coefficients } \\
\text { Beta }\end{array}$} & \multirow[b]{2}{*}{ t } & \multirow[b]{2}{*}{ Sig. } \\
\hline & & B & Std. Error & & & \\
\hline \multirow[t]{2}{*}{1} & (Constant) & -1.094 & .172 & & -6.357 & .000 \\
\hline & XIntelectual Capital & 1.272 & .100 & .819 & 12.676 & .000 \\
\hline
\end{tabular}

a. Dependent Variable: Z Profitabilitas

\begin{tabular}{|c|c|c|c|c|}
\hline \multicolumn{5}{|c|}{ Model Summary } \\
\hline Model & $\mathrm{R}$ & R Square & $\begin{array}{l}\text { Adjusted R } \\
\text { Square }\end{array}$ & $\begin{array}{l}\text { Std. Error of } \\
\text { the Estimate }\end{array}$ \\
\hline 1 & $.819^{a}$ & .670 & .666 & .22907 \\
\hline
\end{tabular}

On the output above, it can be concluded that $X \rightarrow Z$ coefficient value is 1,272 . $R$-square obtained is 0,670 or $67,0 \%$, so that the influence of other variables that affect variable $Z$ (profitability) is $1-0,670=0,330$ or $33 \%$. Thus an error coefficient of 0,330 is obtained, so that the path equation for the first structure is obtained as follows:

$$
Z=1,272 X+0,330
$$

To test the significance of the effect of intellectual capital on profitability, the $t$ test is used with a significance level $(\alpha)$ which is $5 \%$. From the previous output, it was obtained the $t$ value of 12.676 . From the $t$ distribution table, with $\alpha=0.05$ and degrees of freedom $n-2=81-2=79$, for one-party test, the $\mathrm{t}$ table value is 1.664. ( $\mathrm{t}$ count $>\mathrm{t}$ table).

Thus, Intellectual Capital $(\mathrm{X})$ is proven to have a positive and significant effect on Profitability $(\mathrm{Z})$ with a large contribution of $67 \%$, so $\mathrm{H} 1$ is accepted. If the company can develop and develop intellectual capital that is well owned, then the company efficiently in managing the company will be able to increase the company's profit and competitive advantage.

4.2 Relation between intellectual capital and firm's value in banking public subsector that listed in Indonesia Stock Exchange (IDX)

Table 3. Result of intellectual capital - firm's value 


\begin{tabular}{|c|c|c|c|c|c|c|}
\hline \multicolumn{7}{|c|}{ Coefficients $^{a}$} \\
\hline & & \multicolumn{2}{|c|}{ Unstandardized Coefficients } & \multirow{2}{*}{$\begin{array}{c}\text { Standardized } \\
\text { Coefficients } \\
\text { Beta }\end{array}$} & \multirow[b]{2}{*}{$\mathrm{t}$} & \multirow[b]{2}{*}{ Sig. } \\
\hline \multicolumn{2}{|c|}{ Model } & $\mathrm{B}$ & Std. Error & & & \\
\hline \multirow[t]{2}{*}{1} & (Constant) & .722 & .280 & & 2.583 & .006 \\
\hline & XIntelectual Capital & .297 & .163 & .201 & 1.821 & .036 \\
\hline
\end{tabular}

a. Dependent Variable: Y Nilai Perusahaan

\begin{tabular}{|c|c|c|c|c|}
\hline \multicolumn{5}{|c|}{ Model Summary } \\
\hline Model & $\mathrm{R}$ & R Square & $\begin{array}{l}\text { Adjusted R } \\
\text { Square }\end{array}$ & $\begin{array}{l}\text { Std. Error of } \\
\text { the Estimate }\end{array}$ \\
\hline 1 & $.201^{\mathrm{a}}$ & .040 & .028 & .37196 \\
\hline
\end{tabular}

On the output above it can be concluded that the $X \rightarrow Y$ coefficient value is 0,297 . R-square value obtained is 0,040 or $4,0 \%$, so that the influence of other variables affecting the Y variable (firm's value) is $1-0,040=$ 0,960 or $96 \%$. Thus, the error coefficient of 0,960 is obtained, so that the path equation for the second structure is obtained as follows:

$$
Y=0,297 X+0,960
$$

To test the significance of the effect of intellectual capital on firm's value, $t$ test is used with a significance level $(\alpha)$ which is $5 \%$. From the previous output, the $t$ value is 1,821 . From the $t$ distribution table, with $\alpha=0,05$ and degrees of freedom $n-2=81-2=79$, for one-party test, the $t$ table value is 1,664 . ( $t$ count $>t$ table).

Thus, Intellectual Capital $(\mathrm{X})$ is proven to have a positive and significant effect on Firm's Value (Y) with a large contribution of $4 \%$. $\mathrm{H} 2$ accepted.

Results in this study explain that good intellectual resource management will increase the company's market value. Excellent intellectual capital will help the company fulfill the interests of all stakeholders. One of a company's stakeholders is the investor. Capital market investor's will show their acknowledgment for the benefits of intellectual capital owned by a company by investing in it. The additional investment will have an impact on the increase in company value. The effort that management must do to create added value for the company can be done by managing and increasing the intellectual property owned by the company, both employees (human capital), physical assets (employed capital) and structural capital.

\subsection{Relation between profitability and firm's value in banking public subsector that listed in Indonesia Stock Exchange (IDX)}

Table 4. Result of profitability - firm's value

\begin{tabular}{|c|c|c|c|c|c|c|}
\hline \multicolumn{7}{|c|}{ Coefficients $^{a}$} \\
\hline & & \multicolumn{2}{|c|}{ Unstandardized Coefficients } & \multirow{2}{*}{$\begin{array}{c}\text { Standardized } \\
\text { Coefficients } \\
\text { Beta }\end{array}$} & \multirow[b]{2}{*}{$\mathrm{t}$} & \multirow[b]{2}{*}{ Sig. } \\
\hline & & $\mathrm{B}$ & Std. Error & & & \\
\hline \multirow[t]{2}{*}{1} & (Constant) & .995 & .118 & & 8.411 & .000 \\
\hline & Z Profitabilitas & .217 & .104 & .228 & 2.079 & .020 \\
\hline
\end{tabular}

a. Dependent Variable: Y Nilai Perusahaan 
The Influence of Intellectual Capital On the Firm's Value with Profitability as Intervening Variable (Empirical Study on Banking Subsector Companies Listed on the Indonesia Stock Exchange (IDX) of the year 2017-2019)

\begin{tabular}{|c|c|c|c|c|}
\hline \multicolumn{5}{|c|}{ Model Summary } \\
\hline Model & $\mathrm{R}$ & R Square & $\begin{array}{l}\text { Adjusted R } \\
\text { Square }\end{array}$ & $\begin{array}{l}\text { Std. Error of } \\
\text { the Estimate }\end{array}$ \\
\hline 1 & $.228^{a}$ & .052 & .040 & .36970 \\
\hline
\end{tabular}

On the output above, it can be concluded that the $\mathrm{Z} \rightarrow \mathrm{Y}$ coefficient value is 0,217 . R-square value obtained is 0,052 or $5,2 \%$, so that the influence of other variables affecting the Y variable (Firm's Value) is $1-0,052=$ 0,948 or $94,8 \%$. Thus, the error coefficient of 0,948 is obtained, so that the path equation for the third structure is obtained as follows:

$$
\mathrm{Y}=0,217 \mathrm{X}+0,948
$$

To test the significance effect of intellectual capital on firm's value used, with a significance level $(\alpha)$ at 5\% $\mathrm{t}$ test. From the previous output, it was obtained that $\mathrm{t}$ value was 2,079. From $\mathrm{t}$ distribution table, with $\alpha=0,05$ and degrees of freedom $n-2=81-2=79$, for one-party test, the $t$ table value is 1,664 . $(t$ count $>t$ table).

Thus, Profitability $(\mathrm{Z})$ is proven to have a positive and significant effect on Firm's Value (Y) with a large contribution of $5,2 \%$. H3 is accepted.

This shows that the higher financial performance, the more likely there will be an increase in firm's value. Measurement of financial performance can be seen using financial statement analysis or ratio analysis, one of the ratios that would be seen first by investors is the profitability ratio. Profitability shows the level of net profit that a company can achieve when running its operations. When the company manages to book a large profit rate, it will motivate the investors to invest in shares, so the shares price and the demand for shares will increase.

\subsection{Financial performance as an intervening variable in the relation intellectual capital with firm's value} follows:

From previous calculations, a summary of the analysis results of the two path structures is described as

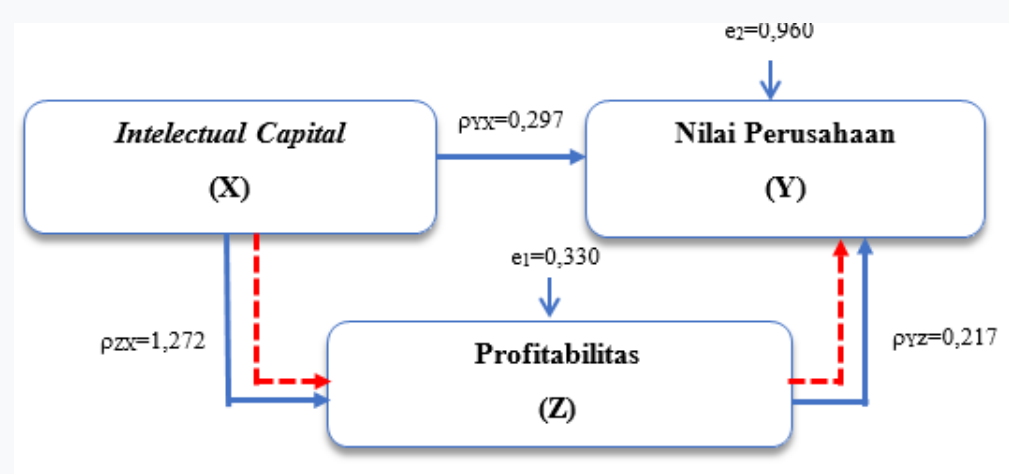

Figure 1. Complete intervening model

The amount of indirect effect of intellectual capital $(\mathrm{X})$ on firm's value $(\mathrm{Y})$ through profitability $(\mathrm{Z})$ is obtained from the multiplication of the beta coefficient $X \rightarrow Z$ and the beta coefficient $Z \rightarrow Y$ as follows:

$$
\text { Effect of Mediation } X \rightarrow Z \rightarrow Y=1,272 \times 0,217=0,276 \text { or } 27,6 \%
$$

To see the significance of the intervening effect, hypothesis testing was carried out using Sobel Test (Ghozali, 2013). Sobel t test value is obtained from calculations using the Sobel Test for the Significance of Mediation Calculator on the website www.danielsoper.com.

The result of the $\mathrm{t}$ value calculation for the intervening profitability variable is 2,118 with a probability value of 0,034 . The $t$ value $(2,118)$ is greater than the t table value for the Sobel test at $\alpha=5 \%$, which is 1,96 , so 
the conclusion is that intellectual capital is proven to have an effect on firm's value through profitability as an intervening variable, with an effect of $27.6 \%$. H4 accepted.

Table 5. Results of financial performance as an intervening variable in the relation intellectual capital with firm's value

Coefficients $^{\mathbf{a}}$

\begin{tabular}{|c|c|c|c|c|c|}
\hline \multirow[t]{2}{*}{ Model } & \multicolumn{2}{|c|}{ Unstandardized Coefficients } & \multirow{2}{*}{$\frac{\text { Standardized Coefficients }}{\text { Beta }}$} & \multirow[t]{2}{*}{$\mathrm{t}$} & \multirow[t]{2}{*}{ Sig. } \\
\hline & $\mathrm{B}$ & Std. Error & & & \\
\hline (Constant) & .722 & .280 & & 2.583 & .012 \\
\hline X Intellectual Capital & .297 & .163 & .201 & 1.821 & .034 \\
\hline (Constant) & .923 & .344 & & 2.685 & .009 \\
\hline 2 X Intellectual Capital & .064 & .284 & .043 & .224 & .013 \\
\hline Z Profitability & .183 & .183 & .193 & 1.003 & .049 \\
\hline
\end{tabular}

a. Dependent Variable: Y Firm Value

On the Table 4 in model 2, it appears that when profitability is included in calculation of the effect of intellectual capital on firm's value, a coefficient of intellectual capital decreased from the previous model to 0,064. However, before Profitability was included the coefficient of intellectual capital on model 1 is 0,297 . It can be known that profitability (ROA) is an intervening variable for the Relation of intellectual capital to firm's value and can also act as an independent variable.

When the resources owned by the company are managed properly, both physical and intellectual resources, it can encourage an increased financial performance for the company which will be responded positively by stakeholders, one of which is the investors. The firm's value will reflect in shares price of the company. The better the stakeholder response, the better the company value.

\section{Conclusion}

Results of testing and previous discussion that has been described is a base to concluded that intellectual capital has a positive effect on profitability in the banking sub-sector companies listed on the IDX of the year 2017-2019, it means that if a company with high intellectual capital can increase company profitability.

This finding also proves intellectual capital has a positive effect on firm's value. Capital market investor's will show their appreciation for intellectual capital owned by a company by investing in those company. The additional investment will automatically increase the firm's value.

Next conclusion is profitability has a positive effect on firm's value. If the company manages to book a large profit rate, it would motivate investors to invest, so the stock price and the demand for shares will increase.

Intellectual capital has a positive effect on firm's value with profitability as an intervening variable. Based on the analysis above, it can be proven that profitability (ROA) is an intervening variable on Relation between intellectual capital and firm's value and can also act as an independent variable.

\section{References}

3. Asikin, Bachtiar; Mohd Haizam Saudi, Roeshartono Roespinoedji (2020). Influence of Return on Assets (ROA) Return on Equity (ROE) and Earning Per Share (EPS) of Stock Price (Survey on Corporate Advertising, Printing, and the Media listed on the Indonesia stock exchange Period 20152019). Solid State Technology, 63(3), 3941-3955.

4. Bontis, N. K. (2000). Intellectual capital and business performance in Malaysian industries. Journal of Intellectual Capital, 1(1), 85-100.

5. Bontis, N., \& Chun, w. c. (2002). The strategic management of intellectual capital and organization knowledge. Oxford University Express.

6. Brigham, F. E., \& Houston, J. F. (2013). Dasar-dasar Manajemen Keuangan. Jakarta: Salemba Empat.

7. Chen, M. C. (2005). An Empirical Investigation of The Relationship Between Intellectual Capital and Firms' Market Value and Financial Performance. Journal of Intellectual Capital, Vol. 6 No.2, 159-176.

8. Ghozali, Imam. 2013. Aplikasi Analisis Multivariate dengan Program IBM SPSS 21 Update PLS Regresi. Semarang: Badan Penerbit Universitas Diponegoro.

9. Gitman, L. J., \& Chad, J. Z. (2012). Principles of Managerial Finance. Pearson Eduaction Limited. 
The Influence of Intellectual Capital On the Firm's Value with Profitability as Intervening Variable (Empirical Study on Banking Subsector Companies Listed on the Indonesia Stock Exchange (IDX) of the year 2017-2019)

10. Handayani, Sri., Suryana, Yosevin Karnawati \& Darmansyah H S. (2020). Intellectual Capital's Contribution to Increasing Competitive Advantage. International Journal of Psychosocial Rehabilitation, 24, 3212-3218.

11. Sunarsih, N. M., \& Mendra, N. P. Y. (2012). Pengaruh Modal Intelektual Terhadap Nilai Perusahaan dengan Kinerja Keuangan sebagai Variabel Intervening pada Perusahaan yang Terdaftar di Bursa Efek Indonesia. Simposium Nasional Akuntansi XV, pp. 1-27.

12. Nugraha, Bayu Sakti., Elva Nuraina. \& Farida Styaningrum (2018). Pengaruh Intellectual Capital Terhadap Nilai Perusahaan Melalui Profitabilitas Sebagai Variabel Intervening (Studi kasus pada perusahaan manufaktur yang terdaftar di BEI). $11^{\text {Th }}$ FIPA Forum Ilmiah Pendidikan Akuntansi, pp. 113.

13. Nuryaman (2015) The Influence of Intellectual Capital on the Firm's Value with the Financial Performance as Intervening Variable. Procedia - Social and Behavioral Sciences, 211, 292-298.

14. Nuryaman \& Christina, V. (2015). Metodologi Penelitian Akuntansi dan Bisnis Teori dan Praktek. Bogor: Ghalia Indonesia.

15. http://katalog.widyatama.ac.id/index.php?p=show_detail\&id=12822\&keywords=nuryaman

16. Oktari, I. G. (2016). Determinan Modal Intelektual (Intellectual Capital) pada Perusahaan Publik di Indonesia dan Implikasinya terhadap Nilai Perusahaan. Simposium Nasional Akuntansi XIX, pp. 1-29.

17. Prastowo, D., \& Julianty, R. (2002). Analisis Laporan Keuangan Konsep dan Aplikasi. Yogyakarta: Unit Penerbit \& Percetakan AMP YKPN.

18. Pulic, A. (2008). The Principles of Intellectual Capital Efficiency - A Brief Description. Croatian Intellectual Capital Center.

19. Rachmawati, Rima; Nijar Kurnia Romdoni \& Siti Ganiah Maulany (2020). Does Disclosure of Intellectual Capital Increase the Profitability of State-Owned Enterprises in Indonesia? Palarch's Journal of Archaeology of Egypt/Egyptology, 17(10), 4074-4083.

20. Rohman, A., \& Cahyo, R. (2013). Pengaruh Intellectual Capital Terhadap Nilai Perusahaan Dengan Kinerja Keuangan Sebagai Variabel Intervening. Jurnal Fakultas Ekonomika Dan Bisnis Universitas Diponegoro Semarang.

21. Sartono, A. (2010). Menejemen Keuangan Teori dan Aplikasi. Yogyakarta: BPFE .

22. Suhendah, R. (2012). Pengaruh Intellectual Capital terhadap Profitabilitas, Produktivitas, dan Penilaian Pasar pada 74 Perusahaan yang Go Public di Indonesia Pada Tahun 2005- 2007. Simposium Nasional Akuntansi 15, pp. 1-29.

23. Sujoko, \& Soebiantoro. (2007). Pengaruh Struktur Kepemilikan Saham, Leverage, Faktor Intern dan Faktor Ekstern terhadap Nilai Perusahaan. Jurnal Manajemen dan Kewirausahaan, 9(1), 41-48.

24. Susanti, Neneng, Vincentia Wahju Widajatun, Muhammad Bayu Aji Sumantri \& Nugi Mohammad Nugraha. (2020). Implications of Intellectual Capital Financial Performance and Corporate Values (Studies on Goods and Consumption Sector 2013-2017 period). International Journal of Psychosocial Rehabilitation, 24(07).

25. Ulum, I. (2009). Intellectual Capital: Konsep dan Kajian Empiris. Yogyakarta: Graha Ilmu.

26. Ulum, Ihyatul, \& Ghozali. (2008). Intellectual Capital Dan Kinerja Keuangan Perusahaan; Suatu Analisis Dengan Pendekatan Partial Least Squares (PLS). Universitas Diponogoro Semarang.

27. Utami, Eristy Mirnda., Neneng Susanti \& R Achmad Drajat S. (2020). Intellectual Capital Through Corporate Values with Profitability as Mediation Variable. International Journal of Psychosocial Rehabilitation, 24(01), 2456-2462.

28. Weston, J., \& Copeland. (2008). Dasar-Dasar Manajemen Keuangan. Jakarta: Erlangga.

29. Winarso, Eddy; Joung Hyun Park (2016). Analysis Profitability of Company Before and After Merger (A case study on the company's merger in 2009 to 2014 are listed in Indonesia Stock Exchange). $1^{\text {st }}$ CAAGA Conference, pp. 1-33.

30. Wijayani, D. R. (2017). Pengaruh Intellectual Capital Terhadap Kinerja Keuangan Perusahaan Publik Di Indonesia (Studi Empiris Pada Perusahaan Manufaktur di BEI 2012-2014). Jurnal Riset Akuntansi dan Bisnis Airlangga, 2(2).

31. Yuniasih, N. W. (2010). Ekplorasi kinerja pasar perusahaan: Kajian berdasarkan modal intelektual (Studi empiris pada perusahaan yang terdaftar di Bursa Efek Indonesia). Simposium Nasional Akuntansi XIII, pp. 1-29. 